\title{
The Common House Gecko, Hemidactylus frenatus Schlegel in Dumeril \& Bibron 1836 (Reptilia: Geklkonidae) in Gujarat, India
}

\author{
Harshil Patel ${ }^{1}$, Vaibhav Naik ${ }^{2}$, and Shantilal Tank ${ }^{1}$
}

${ }^{1}$ Department of Biosciences, Veer Narmad South Gujarat University, Surat - 395007, India (harshilpatel121@gmail.com)

${ }^{2}$ Valsad Pardi, Gopi Street, Valsad - 396001, India

$T^{1}$ he species-rich gekkonid genus Hemidactylus comprises at least 143 currently recognized species (Uetz et al. 2016), of which at least 30 occur in India (Lajmi et al. 2016). These geckos are widely distributed throughout most of the tropical and subtropical regions of the Eastern Hemisphere, the Mediterranean region, and the Americas. In southern Asia, these are the most abundant and diverse nocturnal geckos. The majority of species have relatively small distributions, largely confined to southern Asia and Africa, and just eight species (H. mabouia, H. turcicus, H. brookii, $H$. frenatus, $H$. garnotii, $H$. persicus, $H$. flaviviridis, and $H$. bowringii) are responsible for most of the huge geographical area occupied by the genus (Carranza and Arnold 2006). The first five of these are widely distributed and are present in both the Eastern and Western Hemispheres. Despite considerable variation of shapes and sizes of species within the genus, karyotypic and molecular phylogenetic analyses have revealed cryptic species within taxa (e.g., $H$. bowringii, $H$. brookii, $H$. frenatus, $H$. garnotii, and $H$. platyurus) once thought to be well defined (Carranza and Arnold 2006; McMahan and Zug 2007; Bauer et al. 2010a; Lajmi et al. 2016).

Many species of Hemidactylus are known to have been introduced outside of their native range by human activity, and at least nine species function effectively as human commensals (Carranza and Arnold 2006; Bauer et al. 2010a), leading to the common name (House Gecko) applied to most of these species. Four of the commensal species $(H$. brookii, $H$. parvimaculatus, $H$. frenatus, and $H$. flaviviridis) are purported to have originated on the Indian Subcontinent (Bansal and Karanth 2010; Bauer et al. 2010b).

The Common House Gecko (Hemidactylus frenatus; Fig. 1) is native to southern and southeastern Asia and the Indo-

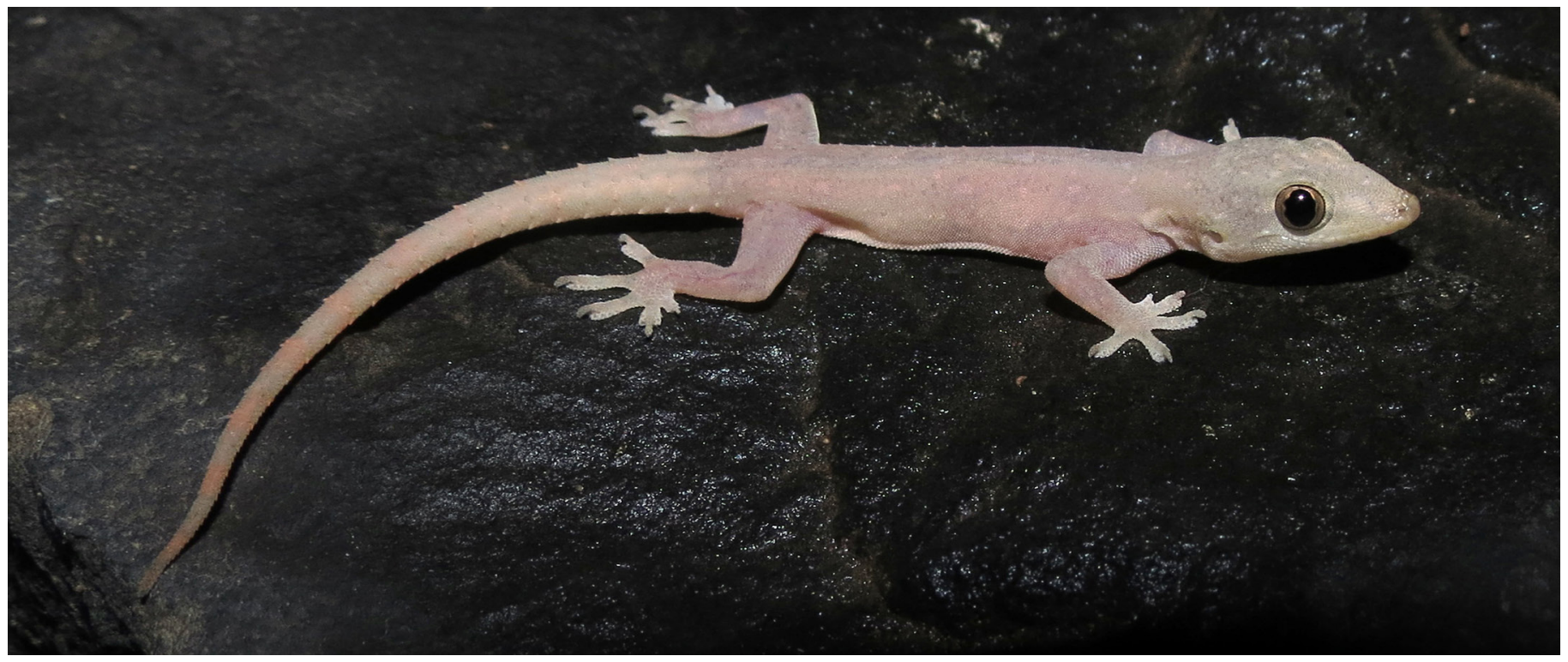

Fig. 1. An adult female Common House Gecko (Hemidactylus frenatus; NCBS AQ031) from Valsad, Gujarat, India. Photograph by H. Patel. 
Australian Archipelago, but it has been widely introduced throughout tropical and subtropical regions of the world (Bauer 1994). The current range of the species includes portions of eastern Africa, Madagascar, many of islands of the South Pacific, Hawaii, Mexico, Central America, and the United States (Rooij 1915; Bauer 1994; Case et al. 1994; Vences et al. 2004).

Unfortunately, very little is known about the distribution of this commensal species in its native habitat, which is further complicated by uncertainties regarding its taxonomic status. Recent phylogenetic studies (Carranza and Arnold 2006; Bansal and Karanth 2010) revealed that $H$. frenatus belongs to the Tropical Asian clade and shows high genetic variability within different populations, suggesting that it is a species complex.

In India, the species, as currently defined, has been recorded from states in southern and eastern parts of the country (Srinivasulu et al. 2014). No confirmed record of $H$. frenatus from the state of Gujarat existed until Vyas (2005) reported this species from four islands of the Marine National Park in the Gulf of Kutch, Gujarat (Fig. 2). Our recent survey revealed its existence for the first time on mainland Gujarat (Fig. 2).

\section{Materials \& Methods}

Three geckos were collected from three different locations in southern Gujarat. All were euthanized, fixed in 10\% formaldehyde, preserved in 70\% alcohol, and deposited in the collection of the National Centre for Biological Sciences (NCBS) in Bangalore: NCBS AQ030, adult male collected from Bilimora, Navsari District, Gujarat, India; NCBS AQ031, subadult female (Fig. 1) collected from Nanakwada, Valsad District, Gujarat, India; NCBS AQ032, juvenile collected from Vesu, Surat District, Gujarat, India. All were collected by $\mathrm{H}$. Patel and V. Naik. In addition to these specimens, we received photographs of a similar gecko taken in Junagadh, Gujarat, from Mr. Pranav Vaghashiya (Fig. 3). Specimens were identified as Hemidactylus frenatus based on descriptions and keys available in the literature (Smith 1935; Vyas 2005; Giri and Bauer 2008; Lajmi et al. 2016).

We made the following measurements using digital callipers (to the nearest $0.01 \mathrm{~mm}$ ): Snout-vent length (SVL; from the tip of the snout to the vent), trunk length (TRL; distance from axilla to groin measured from the posterior edge of the forelimb insertion to the anterior edge of the hindlimb insertion), body width (BW; maximum width of the body),

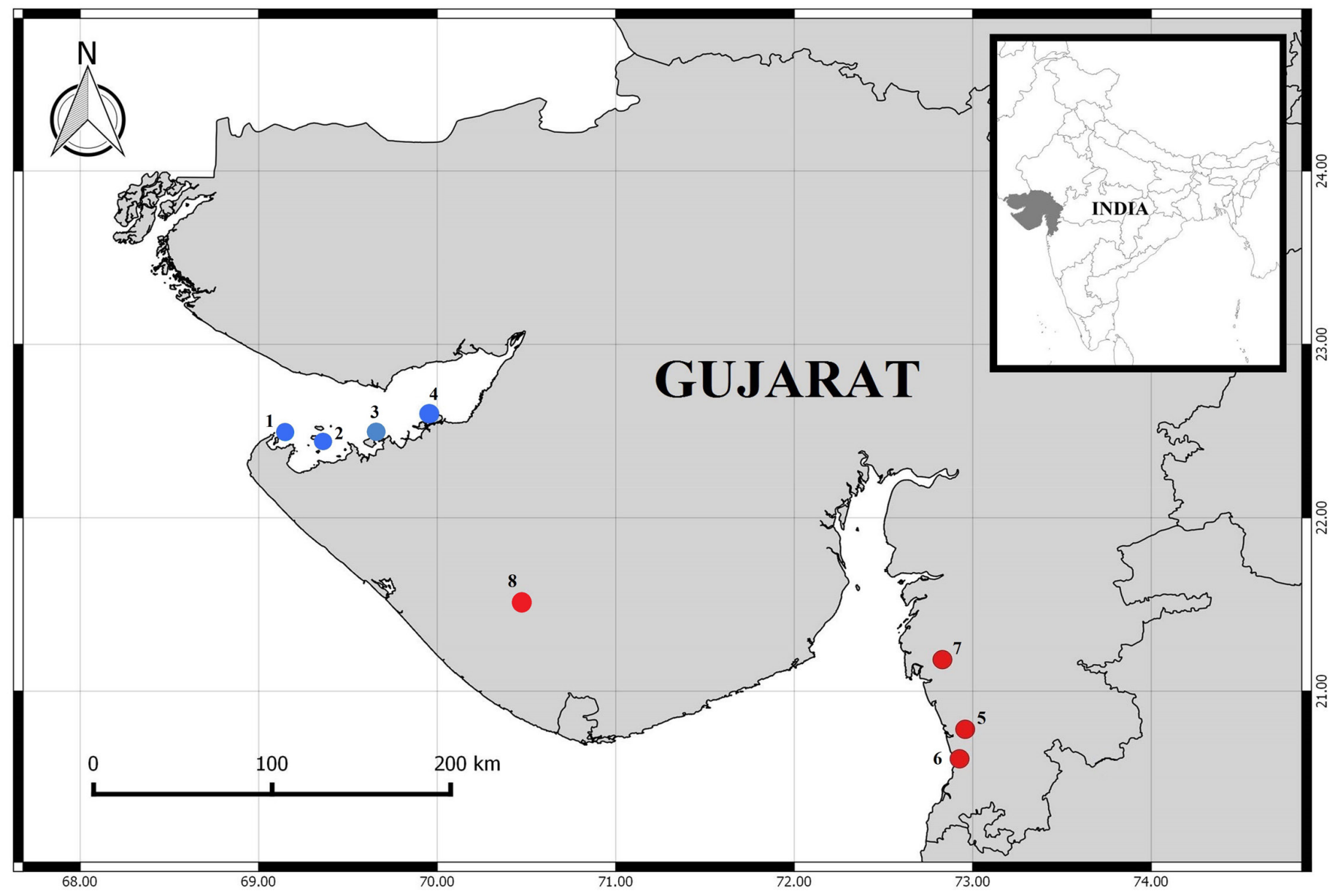

Fig. 2. The known distribution of the Common House Gecko (Hemidactylus frenatus) in Gujarat, India. Blue dots indicate insular populations reported in Vyas (2005); red dots represent new records reported herein. For details, see text and Table 2). 


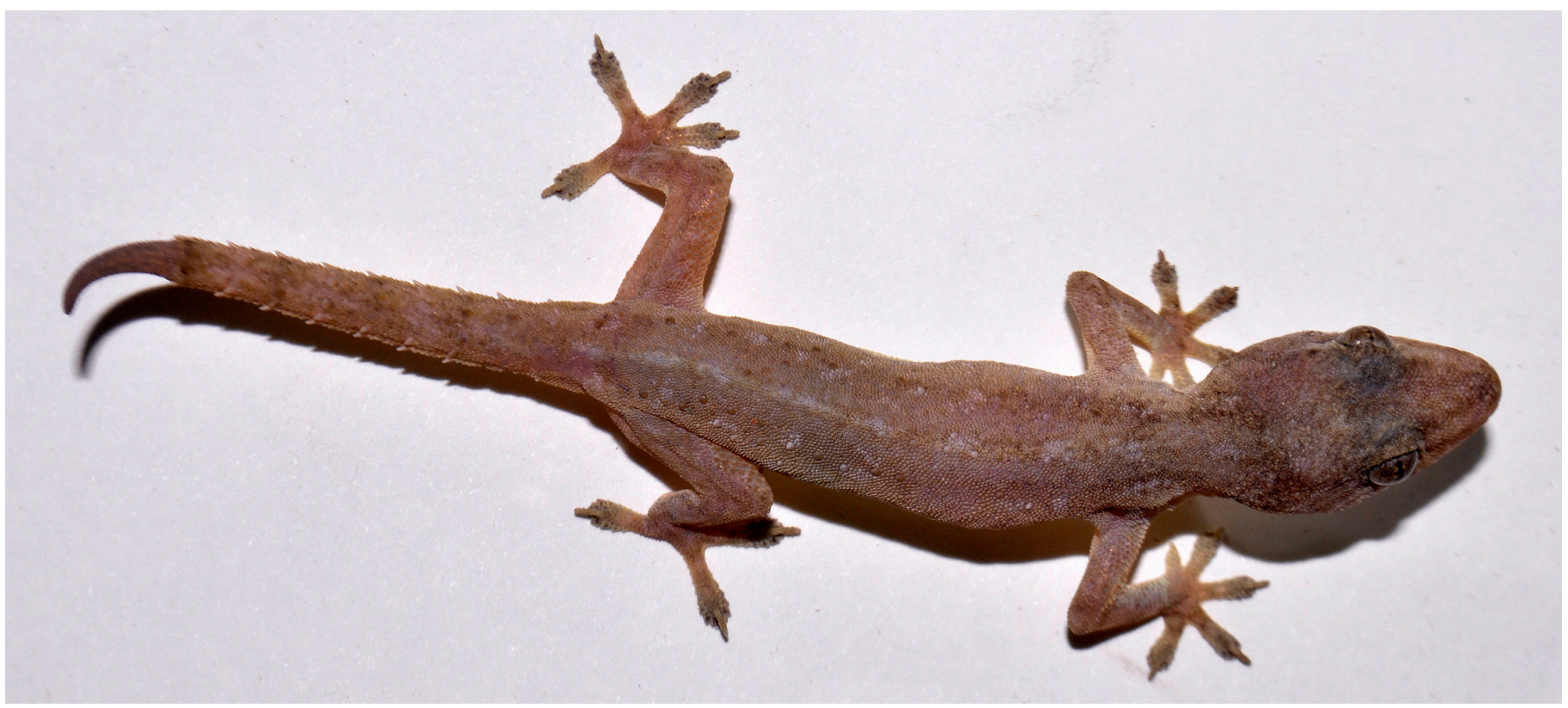

Fig. 3. An adult Common House Gecko (Hemidactylus frenatus) from Junagadh, Gujarat, India. Photograph by P. Vaghashiya.

crus length (CL; from the base of the heel to the knee), tail length (TL; from the vent to the tip of the tail), tail width (TW; measured at the widest point of the tail), head length (HL; distance between retroarticular process of the jaw and the tip of the snout), head width (HW; maximum width of the head), head height $(\mathrm{HH}$; maximum height of the head from the occiput to the underside of the lower jaws), forearm length (FL; from the base of the palm to the elbow), orbital diameter (OD; greatest diameter of the orbit), nares to eye distance (NE; distance between the anteriormost point of the eye and the nostril), snout to eye distance (SE; distance between the anteriormost point of the eye and the tip of the snout), eye to ear distance (EE; distance from the anterior edge of the ear opening to the posterior corner of the eye), ear length (EL; longest dimension of the ear), internarial distance (IN; distance between the nares), and interorbital distance (IO; shortest distance between the left and right supraciliary scale rows). Scale counts and external observations of morphology were made using a Leica S4E stereomicroscope. Some abbreviations used to describe characters include SL (= supralabials) and IL (= infralabials).

\section{Results and Discussion}

Mensural and meristic data of the collected specimens are presented in Table 1. All exhibited features characteristic of the species: Dorsum with small granular, heterogeneous, juxtaposed scales intermixed with regularly arranged, relatively large, conical, smooth tubercles arranged in longitudinal rows on dorsolateral region, extending from the middle of the trunk; ventrolateral skin fold is present on trunk and thigh. Digits moderately dilated, slightly webbed, with lamellae beneath first toe and finger 5; fourth finger 8 and

Table 1. Morphometric and meristic data for three specimens of Common House Geckos (Hemidactylus frenatus) collected on the mainland of Gujarat State, India. All measurements are in $\mathrm{mm} . \mathrm{L}=$ left, $\mathrm{R}=$ right; the asterisk $\left(^{*}\right)$ indicates that the tail was broken and partially regenrated.

\begin{tabular}{|c|c|c|c|}
\hline Character & NCBS AQ030 & NCBS AQ031 & NCBS AQ032 \\
\hline SVL & 48.24 & 36.48 & 30.04 \\
\hline TRL & 20.98 & 13.49 & 11.9 \\
\hline BW & 9.94 & 8.2 & 6.92 \\
\hline $\mathrm{CL}$ & 7.31 & 5.33 & 4.96 \\
\hline TL & $34.56^{*}$ & 40.69 & 34.43 \\
\hline TW & 5.07 & 3.57 & 3.58 \\
\hline HL & 13.22 & 11.84 & 9.48 \\
\hline HW & 9.82 & 8.48 & 6.73 \\
\hline HH & 5.26 & 4.44 & 3.74 \\
\hline FL & 5.09 & 4.14 & 3.63 \\
\hline OD & 3.02 & 2.58 & 2.32 \\
\hline $\mathrm{NE}$ & 11.03 & 9.45 & 8.51 \\
\hline SE & 12.14 & 10.71 & 9.25 \\
\hline EE & 4.56 & 3.26 & 3.02 \\
\hline EL & 1.07 & 0.89 & 0.65 \\
\hline IN & 1.96 & 1.6 & 1.33 \\
\hline IO & 4.9 & 4.54 & 2.74 \\
\hline Sex & Male & Female & Not Determined \\
\hline L Manus & $5-6-7-8-8$ & $5-6-8-8-8$ & $5-7-7-8-8$ \\
\hline R Manus & $5-6-7-8-8$ & $5-6-7-8-8$ & $5-6-7-8-8$ \\
\hline L Pes & $5-7-8-10-9$ & $5-7-9-10-9$ & $5-7-8-10-9$ \\
\hline R Pes & $5-7-8-10-9$ & $5-7-9-10-9$ & $5-8-9-10-9$ \\
\hline SL L/R & $10 / 11$ & $10 / 10$ & $10 / 10$ \\
\hline IL L/R & $10 / 10$ & $9 / 9$ & $9 / 9$ \\
\hline
\end{tabular}




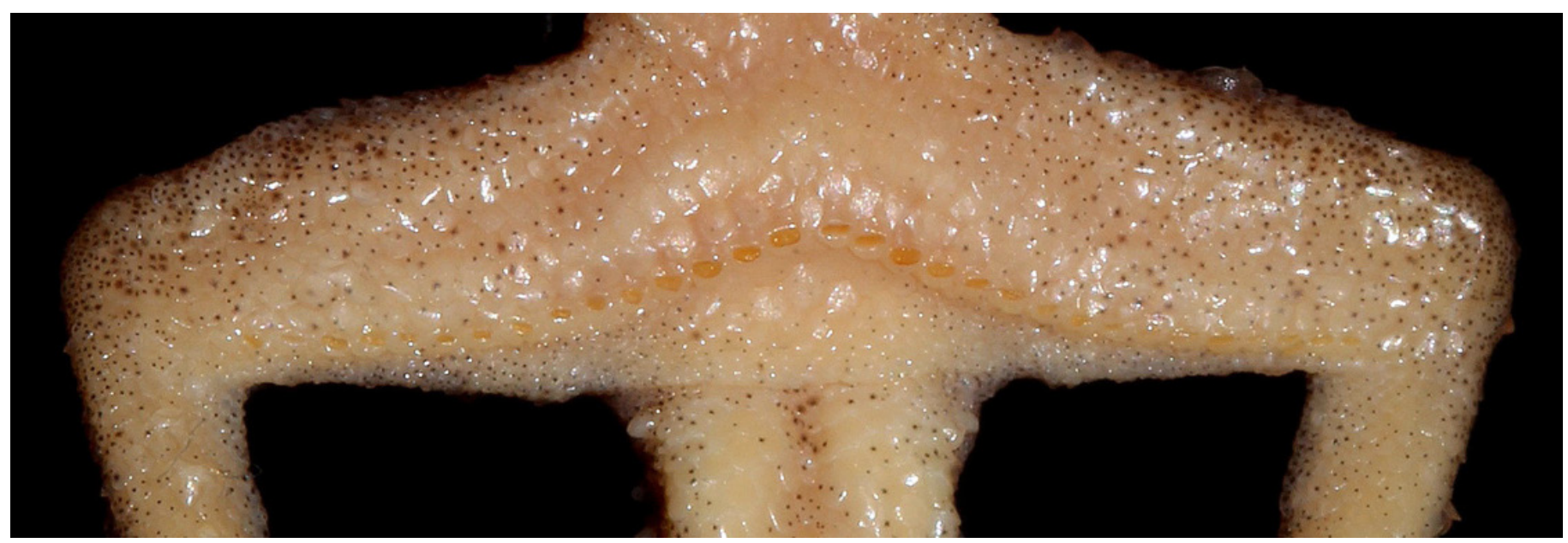

Fig. 4. The precloacal region of an adult male Common House Gecko (Hemidactylus frenatus, NCBS AQ030) showing a series of 31 precloacal-femoral pores, separated medially by one poreless scale. Photograph by H. Patel.

fourth toe 10 . Supralabial scales 10 to 11 , infralabial scales 9 to 10 . Outer postmental in direct contact with infralabials. Precloacal-femoral pores present in a series of 31, interrupted medially by one poreless scale (Fig. 4). Tail moderately depressed, oval in cross section with a series of six enlarged, conical tubercles.

In life, the dorsum was pinkish yellow, slightly darker on the distal half of digits, with indistinct white or creamy white light spots on body and limbs; undersides of the head, body, and most of the limbs were lemon yellow, the underside of the tail was pinkish white.

The present study and information in Vyas (2005) show that this species is distributed in at least three regions of Gujarat: Southern Gujarat, Saurashtra, and islands in the Gulf of Kutch (Table 2). The three specimens we collected were captured after sunset between 2000 to $2200 \mathrm{~h}$. NCBS AQ 030 was in a mango orchard, and NCBS AQ 031 and 032 were edificarian.

Gujarat, the westernmost state of India (Fig. 2), is topographically and ecologically diverse. Most of the major mountain ranges of peninsular India (i.e., Aravalli, Vindhya, Satpura, and the Western Ghats) terminate in Gujarat. The rainshadows of those ranges include extensive xeric regions that are contiguous with those of Rajasthan and Pakistan. However, excepting a few preliminary surveys, Gujarat remains herpetologically unexplored. The recent descriptions of a new gecko, Hemidactylus gujaratensis (Giri et al. 2009), and a new genus of snakes, Wallaceophis (Mirza et al. 2016), from Gujarat indicate that dedicated surveys across the state could yield additional herpetological discoveries.

\section{Acknowledgements}

We thank Kaushal Patel and Ketan Patel for assisting us during fieldwork and Pranav Vaghashiya for providing information and photographs. We also thank Raju Vyas for constant support, encouragement, and discussions regarding this study. The Forest Department of Gujarat issued the necessary research permits. HP was supported by a INSPIRE Fellowship (IF 130480) from the Department of Science and Technology (DST), New Delhi, India.

Table 2. Known localities for Common House Geckos (Hemidactylus frenatus) in Gujarat, India. Numbers correspond to those in Fig. 2.

\begin{tabular}{|c|c|c|c|c|}
\hline No. & Locality & Coordinates & District & Source \\
\hline 1 & Bet Dwarka & $22.44^{\circ} \mathrm{N}, 69.09^{\circ} \mathrm{E}$ & Devbhoomi Dwarka & Vyas (2005) \\
\hline 2 & Ajad Island & $22.37^{\circ} \mathrm{N}, 69.32^{\circ} \mathrm{E}$ & Devbhoomi Dwarka & Vyas (2005) \\
\hline 3 & Kalubhar Island & $22.43^{\circ} \mathrm{N}, 69.61^{\circ} \mathrm{E}$ & Devbhoomi Dwarka & Vyas (2005) \\
\hline 4 & Pirotan Island & $22.59^{\circ} \mathrm{N}, 69.95^{\circ} \mathrm{E}$ & Jamnagar & Vyas (2005) \\
\hline 5 & Bilimora & $20.78^{\circ} \mathrm{N}, 72.97^{\circ} \mathrm{E}$ & Navsari & This study (specimen) \\
\hline 6 & Nanakwada & $20.59^{\circ} \mathrm{N}, 72.92^{\circ} \mathrm{E}$ & Valsad & This study (specimen) \\
\hline 7 & Vesu & $21.15^{\circ} \mathrm{N}, 72.78^{\circ} \mathrm{E}$ & Surat & This study (specimen) \\
\hline 8 & Junagadh & $21.56^{\circ} \mathrm{N}, 70.45^{\circ} \mathrm{E}$ & Junagadh & This study (photograph; Fig. 3) \\
\hline
\end{tabular}




\section{Literature Cited}

Bansal, R. and K.P. Karanth. 2010. Molecular phylogeny of Hemidactylus geckos (Squamata: Gekkonidae) of the Indian subcontinent reveals a unique Indian radiation and an Indian origin of Asian house geckos. Molecular Phylogenetics and Evolution 57: 459-465.

Bauer, A.M. (with K. Henle as a contributor). 1994. Gekkonidae. Part 1, Australia and Oceania. Das Tierreich 109. Walter De Gruyter Publishers, Berlin, Germany.

Bauer, A.M., T.R. Jackman, E. Greenbaum, A. de Silva, V.B. Giri, and I. Das. 2010a. Molecular evidence for the taxonomic status of Hemidactylus brookii group taxa (Squamata: Gekkonidae). Herpetological Journal 20: 129-138.

Bauer, A.M., T.R. Jackman, E. Greenbaum, V.B. Giri, and A. de Silva. 2010 b. South Asia supports a major endemic radiation of Hemidactylus geckos. Molecular Phylogenetics and Evolution 57: 343-352.

Carranza, S. and E.N. Arnold. 2006. Systematics, biogeography, and evolution of Hemidactylus geckos (Reptilia: Gekkonidae) elucidated using mitochondrial DNA sequences. Molecular Phylogenetics and Evolution 38: 531-545.

Case, T.J., D.T. Bolger, and K. Petren. 1994. Invasions and competitive displacement among House Geckos in the Tropical Pacific. Ecology 75: 464-477.

Giri, V.B. and A.M. Bauer. 2008. A new ground-dwelling Hemidactylus (Squamata: Gekkonidae) from Maharashtra, with a key to the Hemidactylus of India. Zootaxa 1700: 21-34.

Giri, V.B., A.M. Bauer, R. Vyas, and S. Patil. 2009. New species of rock-dwelling Hemidactylus (Squamata: Gekkonidae) from Gujarat, India. Journal of Herpetology 43: 385-393.

Lajmi, A., V.B. Giri, and K.P. Karanth. 2016. Molecular data in conjunction with morphology help resolve the Hemidactylus brookii complex (Squamata: Gekkonidae). Organism Diversity \& Evolution 16: 659-677.

McMahan, C.D. and G.R. Zug. 2007. Burmese Hemidactylus (Reptilia, Squamata, Gekkonidae): Geographic variation in the morphology of Hemidactylus bowringii in Myanmar and Yunnan. Proceedings of the California Academy of Sciences 58: 485-509.

Mirza, Z.A., R. Vyas, H. Patel, J. Maheta, and R.V. Sanap. 2016. A new Miocenedivergent lineage of Old World racer snake from India. PloS ONE 11(3): e0148380.

Rooij, N. de. 1915. The Reptiles of the Indo-Australian Archipelago. I. Lacertilia, Chelonia, Emydosauria. Brill, Leiden, Netherlands.

Smith, M.A. 1943. The Fauna of British India, Ceylon and Burma, Including the Whole of the Indo-Chinese Sub-Region. Reptilia and Amphibia. Volume IIISerpentes. Taylor and Francis, London, United Kingdom.

Srinivsaulu, C., B. Srinivasulu, and S. Molur (compilers). 2014. The Status and Distribution of Reptiles in the Western Ghats, India. Conservation Assessment and Management Plan (CAMP). Wildlife Information Liaison Development Society, Coimbatore, Tamil Nadu, India.

Uetz, P., P. Freed, and J. Hošek. 2016. The Reptile Database. (http://www.reptiledatabase.org).

Vences, M., S. Wanke, D.R. Vieites, B. Branch, and F. Glaw. 2004. Natural colonisation or introduction? High genetic divergences and phylogeographic relationships of house geckos (Hemidactylus) from Madagascar. Biological Journal of the Linnean Society 83: 115-130.

Vyas, R. 2005. First record of Asian House Gecko Hemidactylus frenatus (Schlegel) from Gujarat State, Western India. Cobra 60: 13-17. 